\title{
Sweet Potato Purchase Behavior: An Analysis of the Household Decision-Making Process ${ }^{1}$
}

\author{
C. L. Huang, J. E. Epperson and J. M. Law ${ }^{2}$
}

\begin{abstract}
This report relates sweet potato (Ipomoea batatas Poir.) purchases to the characteristics of the homemaker. The analysis does not obtain parameter estimates of the consumption function for sweet potatoes. Rather, it formulates a series of hypotheses for testing that are suggested by economic theory.

A multivariate analysis was applied to the data obtained from a consumer survey regarding purchase of sweet potatoes. The results of this study strongly support the gatekeeper theory in household food consumption. Namely, it was found that the consumer purchases of sweet potatoes were significantly related to the specific characteristics of the homemaker and not those of the household.

This study supports the premise that for better understanding of food purchase behavior further inquiry should focus on the role of the homemaker as the primary decision-maker. Findings reveal implications for the sweet potato industry: promotional efforts should be directed towards the young homemaker, emphasizing ease and quickness of preparation.
\end{abstract}

\section{INTRODUCTION}

There is continuing interest in studying the influence of consumer characteristics on household food. Recognition of the importance of the "household specific" effects has led to incorporating socio-economic and demographic variables directly into the consumption function $(1,5,6,8)$.

Invariably, the household-even though its socio-economic and demographic composition has been explored-is accepted as the basic consuming unit. Decision processes within the household are often considered as intermediate steps in the overall process of maximizing an a priori utility function. Such intermediate steps are implicitly regarded of little consequence in determining consumer behavior.

However, this basic premise may be too simplistic and may restrict the development of realistic parameters which are needed in more encompassing explanatory models. Research, for instance, from family panel data has shown that the influential member of the family affects the economic behavior of the household. ${ }^{3}$ Therefore, in explanations of con-

${ }^{1}$ Manuscript submitted to Editorial Board May 23, 1979.

${ }^{2}$ Assistant Professors of Agricultural Economics, University of Georgia, Georgia Experiment Station, and Professor of Agricultural Economics, Louisiana State University.

${ }^{3}$ Ferber, R. A. and L. C. Lee, 1972. Husband-wife influence in family financial economic behavior. Unpublished Working Paper, Univ. of Ill. Coll. of Comm. and Bus. Admin., found that if the husband is the individual that exerts major influences over family finances, the household is likely to save a higher porportion of its income and to have a higher proportion of its gross assets in terms of real estate and negotiable securities. Purchases of family cars also tend to be less frequent. 
sumer behavior, it may be more prudent to probe deeper than the household unit. Thus, a basic consideration in evaluating household decision-making should be that consumer behavior involves many decisions within the household and varies substantially. The dominant family decision maker varies with the type of consumer goods or services in question.

The "gatekeeper" theory argues that in general the homemaker is responsible for food expenditures at home (4). There is no doubt that decisions regarding food purchases may reflect specific desires of each member in the household. However, the homemaker is considered the ultimate decision-maker and is instrumental in the formation of household food habits.

The objective of this study is to formulate a statistically testable hypothesis of the gatekeeper theory, using information obtained from a consumer survey regarding purchase of sweet potatoes. If the homemaker's family role is independent of household food consumption, then food purchase factors associated with the characteristics of the homemaker would be due strictly to chance and such factors would hardly be relevant for food consumption functions or economic models. Otherwise, homemaker characteristics such as age, education, employment status, knowledge of nutrition and attitude toward food preparation can be expected to be the determinant factors in establishing food consumption patterns of the entire household.

\section{DATA AND METHODS}

SAMPLE

This analysis utilizes information collected from a consumer survey in five cities of the Northeastern United States during 1975. The survey was designed to provide insight into effective marketing, promotion, and merchandising of sweet potatoes. Information of consumer attitudes toward sweet potatoes was obtained by personal interview with the individual who usually is identified as the homemaker and primarily responsible for food purchase decisions. The sample consisted of 2,525 households selected at random from geographic strata of the metropolitan areas of Milwaukee (Wisconsin), Cincinnati (Ohio), Pittsburgh (Pennsylvania), Rochester (New York), and Boston (Massachusetts). The data was collected primarily on the basis of attitude responses of sweet potato users. Approximately $17 \%$ of the sample households were nonusers. However, information regarding household and homemaker characteristics was obtained for both users and nonusers. For purposes of this analysis were observations deleted where certain key information concerning socio-economic characteristics was not reported. 


\section{ANALYTICAL PROCEDURE}

A multivariate analysis was applied to data to test relationships between household purchases of sweet potatoes and household characteristics. Since the nature of the sample data is primarily qualitative, the regression model is not well suited for such a test. The Chi-square contingency table test was employed to examine the merits of the proposition that the characteristics of homemakers are linked to the consumption patterns of sweet potatoes. However, the test does not specify in what ways the relationships may exist.

Multivariate analysis is appropriate in this case since several homemaker characteristics are examined. If each characteristic is tested alone, possible correlation between characteristics is ignored; thus there is possible distortion of the real significance levels for test statistics (2). The values of Bonferroni $\chi^{2}$ statistics, which take into account not only the degrees of freedom for each test but also the number of test hypotheses,

TABLE 1.-Summary of results from multivariate analysis of sweet potatoes purchased in five northeastern United States cities

\begin{tabular}{lcccl}
\hline \multicolumn{1}{c}{ Hypothesis } & $\begin{array}{c}\text { Value of sta- } \\
\text { tistics }\end{array}$ & $\begin{array}{c}\text { Degrees of } \\
\text { freedom }\end{array}$ & $\begin{array}{c}\text { Bonferroni } \chi^{2} \\
\chi^{2}(0.05,5, \mathrm{v})^{2}\end{array}$ & \multicolumn{1}{c}{ Conclusion } \\
\hline 1. Type of employment of & 10.577 & 8 & 20.090 & Cannot reject \\
$\quad \begin{array}{l}\text { household head } \\
\text { 2. Income level of household }\end{array}$ & 2.898 & 6 & 16.812 & Cannot reject \\
3. Age of homemaker & 40.810 & 4 & 13.277 & Reject \\
4. Education of homemaker & 8.509 & 3 & 11.345 & Cannot reject \\
5. Race of household & 5.222 & 1 & 6.635 & Cannot reject \\
\hline
\end{tabular}

${ }^{1}$ The Bonferroni $\chi^{2}$ statistics are represented by $\chi^{2}(\alpha, t, v)$ where $\alpha$ is the nominal significance level, $t$ is the number of hypotheses tested and $v$ is the number of degrees of freedom for each test. The Bonferroni $\chi^{2}$ tables can be found in (3).

are used to provide the critical values for the various hypotheses such that the probability of incorrectly rejecting one or more of the hypotheses is no greater than $\alpha$, the nominal level of significance (3).

\section{RESULTS}

The analysis has been confined to the case in which there is only one explanatory characteristic to be tested for each hypothesis. Specifically, the dependent variable in question, purchase of sweet potatoes (user vs. nonuser), is tested against one explanatory variable to determine whether there is a relationship between the two variables. Five demographic variables, associated with the household and/or homemaker of the household, which are expected to affect the purchase of sweet potatoes are examined. Table 1 presents the results of the multivariate analysis. It should be noted that if the usual procedure of $\chi^{2}$ contingency table test is used and not the simultaneous test, hypotheses 4 and 5 (table 1) would be rejected at the $5 \%$ significance level. 
It has been noted previously that the results of the hypotheses testing would suggest relationships only if the null-hypothesis of independence between the dependent and explanatory variables can be rejected at a certain predetermined significance level. It does not suggest in what specific ways household purchasing behavior may differ. To provide evidence in this regard a comparison of observed and "expected" frequencies can be useful. ${ }^{4}$ Table 2 presents the discrepancies between expected and observed frequencies in testing hypothesis 3.

In this instance, there are no difficulties with the interpretation of the difference between the expected and actual observations (table 2). There seems to be a distinct directional relationship between the purchase of sweet potatoes and the age of the homemaker. In other words, a homemaker who is 36 years age or older is more likely to purchase sweet potatoes for household consumption than a homemaker who is under 36 years of age.

TABLE 2.-Differences between observed and expected frequency distributions for the purchase of sweet potatoes concerning age of homemaker

\begin{tabular}{ccc}
\hline Age group & \multicolumn{2}{c}{ Households } \\
\cline { 2 - 3 } & Users & Nonusers \\
\hline Under 25 & -11.266 & 11.266 \\
$25-35$ & -41.125 & 41.125 \\
$36-50$ & 21.176 & -21.176 \\
$51-65$ & 27.879 & -27.879 \\
66 and over & 3.336 & -3.336 \\
\hline
\end{tabular}

\section{DISCUSSION}

The underlying concept of many previous studies appears to be that the household is the basic economic unit to be considered in decisionmaking with respect to food demand and consumption behavior. But this is not so in the process involved in decision-making regarding family food behavior. The smallest economic unit responsible for the formation of household food habits is often the homemaker and not the family. This report suggests that household characteristics which are not specifically the homemaker's-such as type of employment of household head, and income-have little to do with sweet potato purchases. However, evidence provided by the analysis does suggest a link between age of the homemaker and sweet potato consumption. Although not highly significant, the educational level and race of the homemaker are also found to be related to sweet potato consumption.

The potential for relating food consumption behavior to homemaker's activities in provisioning their families is usually overlooked (7). Infor-

${ }^{4}$ The expected frequencies are formulated under the assumption of independence in probability. For further discussion of the development of the theoretical model, see (2). 
mation about homemakers can provide important clues in studying the behavioral patterns of household food consumption. Employment status of the homemaker has significant impact on away-from-home food consumption and can lead to more use of convenience foods (6). Younger homemakers who have more recent information on food and nutrition are more likely to be flexible in their food choices and apt to change food consumption patterns. If it is the homemaker, and not the household, who is actually responsible for decision making in food consumption, the problems associated with nutrition and food consumption may be solved largely by influencing the behavior of individual homemakers.

Based on findings presented in this paper, definitive implications for the sweet potato industry emerge. In order to preserve or improve consumer demand for sweet potatoes, the industry should direct its promotion efforts toward creating or increasing preference for sweet potatoes among young homemakers. Further, the course of such promotion should emphasize ease and quickness of preparation.

\section{RESUMEN}

Este informe relaciona la compra de batatas (Ipomoea batatas Poir.) con las características del ama de casa. El análisis no ofrece estimados de los parámetros de la función de consumo de la batata; más bien formula una serie de hipótesis para pruebas sugeridas por la teoría económica.

A los datos obtenidos en un survey de consumo relacionado con la compra de batatas se le aplicó un análisis de variables múltiples. Los resultados respaldan la teoría "gatekeeper" para el consumo de alimentos de la familia. Se encontró que la compra de batatas estaba relacionada significativamente con características específicas del ama de casa y no con los de la familia.

El estudio respalda la premisa de que, para comprender mejor la peculiaridad en la compra de alimentos se debe estudiar más a fondo el papel que desempeña el ama de casa como la persona que toma las decisiones. Los resultados revelan que la promoción debe dirigirse al ama de casa joven ya que la batata es fácil y rápida de preparar.

\section{LITERATURE CITED}

I. Adrian, J. and Daniel, R., 1976. Impact of Socioeconomic Factors on Consumption of Selected Food Nutrients in the United States, Am. J. Agric. Econ., 58, 31-8.

2. Brownlee, K. A., 1965. Statistical Theory and Methodology in Science and Engineering, John Wiley \& Sons, New York, N.Y.

3. Kramer, C. Y., 1972. A First Course in Methods of Multivariate Analysis. Blacksbury, Va: Va. Polytech. Inst.

4. Lewin, K., 1942. Forces Behind Food Habits and Methods of Change. In The Problems of Changing Food Habits, Nat. Res. Counc. Bull. 108. 
5. Mathia, G. E., 1975. An Economic Evaluation of Consumer Characteristics Affecting Sweet Potato Consumption, J. Am. Soc. Hort. Sci., 100: 529-31.

6. Prochaska, F. J. and Schrimper, R. A., 1973. Opportunity Cost of Time and Other Socioeconomic Effects on Away-from-home Food Consumption, Am. J. Agric. Econ. 55: 595-603.

7. Protein-Calorie Advisory Group of the United Nations System, 1977. Women in Food Production, Food Handling and Nutrition, Protein-Calorie Advisory Group Bull. 7 (3-4).

8. Purcell, J. C. and Raunikar, R., 1967. Quantity-income Elasticities for Foods by Level of Income, J. Farm Econ. 49: 1410-4. 